\title{
Growth Energetics of Rhizobium leguminosarum in Chemostat Culture
}

\author{
By HOWARD D. RATCLIFFE, ${ }^{\dagger} \dagger$ JAN W. DROZD ${ }^{1 *}$ AND ALAN T. BULL ${ }^{2} \ddagger$ \\ ${ }^{1}$ Shell Research Ltd, Sittingbourne Research Centre, Sittingbourne, Kent ME9 8 AG, U.K. \\ ${ }^{2}$ Department of Applied Biology, University of Wales Institute of Science and Technology, \\ King Edward VII Avenue, Cardiff CF1 3NU, U.K.
}

(Received 28 June 1982; revised 22 November 1982)

\begin{abstract}
The efficiency of oxidative phosphorylation in symbiotic nitrogen-fixing bacteria of the genus Rhizobium in the root nodules of leguminous plants is of fundamental importance as it influences the efficiency of ATP generation from the oxidation of plant photosynthate for the ATPdependent process of nitrogen fixation. A poor efficiency of energy coupling was found for Rhizobium leguminosarum grown glucose-limited in chemostat culture as indicated by low growth yields on glucose $\left[Y_{\text {glucose }}^{\max }=80.3 \mathrm{~g}\right.$ dry wt bacteria $\left.(\mathrm{mol} \text { glucose })^{-1}\right]$ and $O_{2}\left[Y_{\text {oxygen }}^{\max }=25.6 \mathrm{~g}\right.$ dry wt bacteria $\left(\mathrm{mol} \mathrm{O}_{2}\right)^{-1}$. (These values are low when compared with those for aerobic heterotrophic bacteria which have two or three sites of oxidative phosphorylation.) Although $\mathrm{H}^{+} / \mathrm{O}$ measurements suggested a potential $\mathrm{P} / \mathrm{O}$ ratio of 3 there was a very rapid rate of proton decay across the cell membrane; this coupled with the low growth yields suggested that the actual $\mathrm{P} / \mathrm{O}$ ratio was nearer 1 . Under conditions of excess dissolved oxygen cytochromes of the $c$, $b, o$ and $a a_{3}$ types were detected. Under oxygen limitation a $d$ type terminal cytochrome oxidase was also produced and was associated with a further decrease in the efficiency of energy conservation. It remains to be seen whether such a low efficiency of energy conservation is expressed by $R$. leguminosarum within the root nodules of a host legume.
\end{abstract}

\section{INTRODUCTION}

An estimation of the $\mathrm{P} / \mathrm{O}$ ratio in bacteroids and free-living rhizobia is important in relation to the energetics of biological nitrogen fixation in plants. The supply of oxidizable plant photosynthate, and hence energy, may be a factor which under certain conditions can limit nitrogen fixation in legumes (Ratcliffe et al., 1980). The efficiency of energy coupling in the bacteroids will be a major factor which governs the amount of ATP available for nitrogen fixation from the oxidation of plant photosynthate. Studies on ATP production (Appleby et al., 1975; Bergersen \& Turner, 1975), terminal cytochrome oxidases (Bergersen \& Turner, 1980), membrane energization (Laane et al., 1978), and $\mathrm{H}^{+} / \mathrm{O}$ measurements in bacteroids (Ratcliffe et al. 1980) have indicated that the maximum potential $\mathrm{P} / \mathrm{O}$ ratio may approach 3 . Less is known about the efficiency of energy conservation in free-living rhizobia.

The efficiency of energy conservation in bacteria may depend on the respiratory chain composition. Measurements of whole cell $\mathrm{H}^{+} / \mathrm{O}$ ratios and maximum growth yields with respect to the utilization of $\mathrm{O}_{2}$ or the carbon/energy source indicate that the absence of cytochrome $c$ in some species may be associated with a decrease in the potential $\mathrm{P} / \mathrm{O}$ ratio from 3 to 2 (Jones et $a l .$, 1977). Within a species the partial or complete replacement of cytochrome oxidases $a a_{3}$ by $o$ had no significant effect on the potential P/O ratio (Jones et al., 1977; Farmer \& Jones, 1976).

† Present address: Biotechnology Department, Kuwait Institute for Scientific Research, P.O. Box 24885, Safat, Kuwait.

$\ddagger$ Present address: Biological Laboratory, University of Kent at Canterbury, Canterbury, Kent CT2 7NJ, U.K.

Abbreviation: $\mathrm{TMPDH}_{2}, N, N, N^{\prime}, N^{\prime}$-tetramethyl-p-phenylenediamine dihydrochloride, reduced. 
However, replacement of either $o$ or $a a_{3}$ by cytochrome oxidase $d$ (e.g. under conditions of $\mathrm{O}_{2}$ limitation) in the presence of cytochrome $c$ decreases the efficiency of respiratory chain energy conservation (Jones, 1978). In addition to changes in respiratory chain composition the permeability of the cell membrane to protons may influence the efficiency of energy conservation (Ratcliffe et al., 1979; McKay et al., 1982); when the membrane is highly permeable to protons the organisms must respire rapidly to maintain the necessary transmembrane protonmotive force (the $\mathrm{H}^{+} /$ATP ratio is greater than 2) and this leads to a low $\mathrm{P} / \mathrm{O}$ ratio.

In this work we have estimated the efficiency of energy conservation in $R$. leguminosarum grown with a minimal salts medium in chemostat culture under glucose and oxygen limitations. Growth efficiencies were estimated from measurements of growth yields on $\mathrm{O}_{2}$ and glucose and by $\mathrm{H}^{+} / \mathrm{O}$ measurements and were correlated with the cytochrome content of the bacteria. A preliminary report of this work (Ratcliffe et al., 1979) indicated that there was a low efficiency of energy conservation due to a high membrane permeability to protons and is supported by the low yields on oxygen for the growth of $R$. trifolii grown with a complex medium in chemostat culture (de Hollander et al., 1979).

\section{METHODS}

Organism. Rhizobium leguminosarum TA 101, a gift from Dr J. C. Burton, Nitragin Sales Corporation, Milwaukee, Wisconsin, U.S.A., was maintained on yeast extract mannitol agar plates at $4{ }^{\circ} \mathrm{C}$ and subcultured monthly.

Medium. Bacteria were grown in a medium, designed to give glucose limitation, which contained $\left(\mathrm{g}^{-1}\right)$ : glucose, 8.0; $\left(\mathrm{NH}_{4}\right)_{2} \mathrm{SO}_{4}, 3.3 ; \mathrm{KH}_{2} \mathrm{PO}_{4}, 0.34 ; \mathrm{Na}_{2} \mathrm{HPO}_{4}, 0.355 ; \mathrm{MgSO}_{4} .7 \mathrm{H}_{2} \mathrm{O}, 0.11 ; \mathrm{FeSO}_{4} .7 \mathrm{H}_{2} \mathrm{O}, 0.025 ;$ $\mathrm{CaCl}_{2} .2 \mathrm{H}_{2} \mathrm{O}, 0.33$; nitrilo-triacetic acid, 0.05 ; calcium pantothenate, $2.0 \mathrm{mg}$; thiamin. $\mathrm{HCl}, 1.5 \mathrm{mg}$; biotin, $6.0 \mu \mathrm{g}$ and $4.5 \mathrm{ml}$ trace elements solution containing $\left(\mathrm{g} \mathrm{l}^{-1}\right): \mathrm{CuSO}_{4} .5 \mathrm{H}_{2} \mathrm{O}, 0 \cdot 025 ; \mathrm{ZnSO}_{4} \cdot 7 \mathrm{H}_{2} \mathrm{O}, 0 \cdot 16 ; \mathrm{MnSO}_{4} \cdot 4 \mathrm{H}_{2} \mathrm{O}$, $0.20 ; \mathrm{CoCl}_{2} .2 \mathrm{H}_{2} \mathrm{O}, 0.002 ; \mathrm{Na}_{2} \mathrm{MoO}_{4} .2 \mathrm{H}_{2} \mathrm{O}, 0.24 ; \mathrm{KI}, 0.16 ; \mathrm{H}_{3} \mathrm{BO}_{3}, 0.08$ and $5 \mathrm{ml} 1.0 \mathrm{M}-\mathrm{H}_{2} \mathrm{SO}_{4}$.

The medium (30 l) was sterilized by autoclaving at $121^{\circ} \mathrm{C}$. Glucose, $\mathrm{MgSO}_{4} \cdot 7 \mathrm{H}_{2} \mathrm{O}$ and $\mathrm{CaCl}_{2} \cdot 2 \mathrm{H}_{2} \mathrm{O}$ were autoclaved separately and added aseptically when the medium was at room temperature. Solutions of vitamins, $\mathrm{FeSO}_{4} .7 \mathrm{H}_{2} \mathrm{O}$ and $\left(\mathrm{NH}_{4}\right)_{2} \mathrm{SO}_{4}$ were filter-sterilized (Millipore $0.45 \mu \mathrm{m}$ filter) before aseptic addition to the medium reservoir.

Chemostat. A stirred (600 r.p.m.) Biotec fermenter (LKB) with a modified head plate to take a direct drive assembly was used. The culture temperature was maintained at $28.0^{\circ} \mathrm{C} \pm 0.5^{\circ} \mathrm{C}$, the $\mathrm{pH}$ at $6.8 \pm 0.02$ by the addition of $0.75 \mathrm{M}-\mathrm{KOH} / 0.25 \mathrm{M}-\mathrm{NaOH}$, and the culture working volume at approximately 2.51 . The gas supply was air (300 to $\left.600 \mathrm{ml} \mathrm{min}^{-1}\right)$ except for studies on oxygen limitation where air/nitrogen mixtures were used.

Gas composition. A fully automatic computerized gas chromatograph system (for $\mathrm{O}_{2}, \mathrm{CO}_{2}$ and $\mathrm{N}_{2}$ ) was used to determine in situ $\mathrm{O}_{2}$ uptake or $\mathrm{CO}_{2}$ production rates. The gases were separated by the modified gas chromatographic method of Deans et al. (1971). Helium was the carrier gas.

Hydrogen was assayed using the katharometer detector on a Varian model 3700 gas chromatograph. A $5 \AA$ molecular sieve column of length $6 \mathrm{ft}(1.8 \mathrm{~m})$ and internal diameter $\frac{1}{8}$ in $(3.2 \mathrm{~mm})$ was used with $\mathrm{N}_{2}$ as the carrier gas $\left(20 \mathrm{ml} \mathrm{min}^{-1}\right)$ at $60^{\circ} \mathrm{C}$. The outlet from the fermenter was passed through a $50 \mathrm{ml}$ conical flask with a Suba-seal stopper for $30 \mathrm{~min}$. Samples were removed from the flask for the assay.

Bacterial dry weight. Samples of the culture $(25 \mathrm{ml})$ were washed twice with distilled water and dried to constant weight (Linton et al., 1975).

Total bacterial carbon. Analysis of total culture carbon and supernatant carbon was made with a Beckman model 915 total organic carbon analyser (Linton et al., 1975).

Glucose assay. The glucose concentrations in the medium and supernatant were measured by either the glucose oxidase system (Boehringer Glucose Oxidase Test Kit, ser. no. 124028) or a UV system (Boehringer GlucoseFructose, UV Test Kit, ser. no. 139106).

Carbon, hydrogen and nitrogen analysis. The percentage of elemental carbon, hydrogen and nitrogen in freezedried samples of bacteria was determined with a Hewlett-Packard $185 \mathrm{C}, \mathrm{H}$ and $\mathrm{N}$ analyser according to manufacturer's instructions.

Cytochrome content. The cytochrome content of bacteria was determined as previously described (Ratcliffe et al., 1980).

$\mathrm{H}^{+} / \mathrm{O}$ ratios. $\mathrm{H}^{+} / \mathrm{O}$ ratios [g equiv. $\mathrm{H}^{+}$translocated (g equiv. $\mathrm{O}$ consumed) ${ }^{-1}$ ] were measured as previously described (Mitchell \& Moyle, 1967; Jones et al., 1975). The $t_{\frac{1}{2}}$ for collapse of the pulses was calculated from a plot of the log of peak height against time (Mitchell \& Moyle, 1967).

Potential respiration rates of bacteria. Bacteria were harvested from the chemostat, washed and diluted in complete mineral salts medium minus the carbon and nitrogen sources. The respiration rates $\left[q_{\mathrm{O}_{2}} ; \mathrm{mmol} \mathrm{O}_{2}\right.$ 
Table 1. In situ rates of substrate uptake by $R$. leguminosarum grown glucose-limited in continuous culture, $\mathrm{pH} 6 \cdot 8,28^{\circ} \mathrm{C}$

The correlation coefficient for $q_{\text {glucose }}$ is 0.996 and for $q_{\mathrm{O}_{2}}$ is 0.975 . Data are based on least square fit analysis. Values for $q$ were determined as described in Methods. Organic carbon in the supernatant was at or below the limits of detection.

\begin{tabular}{|c|c|c|c|}
\hline $\begin{array}{l}\text { Dilution } \\
\text { rate } \\
\left(\mathrm{h}^{-1}\right)\end{array}$ & $\begin{array}{c}q_{\text {glucose }} \\
{[\text { mmol glucose consumed }} \\
\left.(\mathrm{g} \text { bacteria })^{-1} \mathrm{~h}^{-1}\right]\end{array}$ & $\begin{array}{c}q_{\mathrm{O}_{2}} \\
{\left[\mathrm{mmol} \mathrm{O}{ }_{2} \text { consumed }\right.} \\
\left.(\mathrm{g} \text { bacteria })^{-1} \mathrm{~h}^{-1}\right]\end{array}$ & $\begin{array}{c}\text { Carbon } \\
\text { recovery } \\
(\%)\end{array}$ \\
\hline 0.05 & 0.66 & $2 \cdot 10$ & 115 \\
\hline 0.075 & 0.97 & $2 \cdot 68$ & 104 \\
\hline $0 \cdot 10$ & $1 \cdot 31$ & $4 \cdot 27$ & 98 \\
\hline 0.13 & 1.63 & 4.98 & 106 \\
\hline
\end{tabular}

Table 2. Elemental carbon, hydrogen and nitrogen analysis of $R$. leguminosarum organisms grown under glucose limitation, $\mathrm{pH} 6 \cdot 8,28^{\circ} \mathrm{C}$

Bacteria were harvested from the chemostat, centrifuged, washed twice with distilled water $\left(5^{\circ} \mathrm{C}\right)$ and freeze-dried before analysis (see Methods). Percentages are expressed on a dry weight basis.

$\begin{array}{cccc}\begin{array}{c}\text { Dilution } \\ \text { rate } \\ \left(\mathrm{h}^{-1}\right)\end{array} & \begin{array}{c}\text { Carbon } \\ (\%)\end{array} & \begin{array}{c}\text { Hydrogen } \\ (\%)\end{array} & \begin{array}{c}\text { Nitrogen } \\ (\%)\end{array} \\ 0.05 & 46.7 & 7.3 & 12.7 \\ 0.075 & 45.6 & 7.0 & 12.4 \\ 0.10 & 44.8 & 6.7 & 10.9 \\ 0.13 & 45.0 & 6.9 & 11.1 \\ 0.16 & 45.1 & 6.9 & 10.9\end{array}$

consumed ( $\mathrm{g}$ bacterial dry $\mathrm{wt})^{-1} \mathrm{~h}^{-1}$ ] of intact bacteria were measured on addition of known quantities of substrate by following $\mathrm{O}_{2}$ uptake as measured polarographically at $28^{\circ} \mathrm{C}$ in an oxygen electrode respirometer (Rank Bros, Bottisham, Cambridge).

Dissolved oxygen. The dissolved oxygen tension (DOT) was measured with a galvanic oxygen electrode (L. H. Engineering Co. Ltd, Stoke Poges, Buckinghamshire). The electrode was calibrated against air and nitrogen. The DOT was converted into concentration assuming air saturated medium at $28^{\circ} \mathrm{C}, 760 \mathrm{mmHg}$ pressure to contain $240 \mu \mathrm{M}$ oxygen.

Calculation of bacterial yields on glucose and oxygen. All these yields were calculated from the in situ substrate uptake rates in the chemostat (Linton et al., 1975).

\section{RESULTS}

\section{Determination of biomass yields on glucose and oxygen}

The yield values (corrected for maintenance substrate consumption) calculated from the in situ substrate uptake data (Table 1 ) for $R$. leguminosarum grown aerobically under glucose limitation were: $Y_{\text {glucose }}^{\max }, 80 \cdot 3 \mathrm{~g}$ dry wt bacteria (mol glucose) $)^{-1} ; Y_{\mathrm{O}_{2}}^{\max }, 25.6 \mathrm{~g}$ dry wt bacteria $\left(\mathrm{mol} \mathrm{O}_{2}\right)^{-1}$. An equation adapted from Herbert (1976) was used to check the $R$. leguminosarum yields even though the experimental results showed good carbon recovery values (Table 1) and the correlation coefficient for the data points of $q_{\mathrm{O}_{2}}$ or $q_{\text {glucose }}$ versus $D$ (Table 1 ) was near unity. The equation was adapted to include the nitrogen source:

$$
a \mathrm{C}_{6} \mathrm{H}_{12} \mathrm{O}_{6}+b \mathrm{O}_{2}+x \mathrm{NH}_{3} \rightarrow c \mathrm{CH}_{2} \mathrm{O}_{0.55} \mathrm{~N}_{0.25}+d \mathrm{CO}_{2}+e \mathrm{H}_{2} \mathrm{O}
$$

If a value for $Y_{\text {glucose }}$ is assumed then a corresponding value for $Y_{\mathrm{O}_{2}}$ can be calculated when the equation is balanced with respect to $a, b, c, d, e$ and $x$. The amount of carbon, hydrogen and nitrogen in $c$, i.e. the dry bacteria, can be calculated from elemental analysis of freeze-dried bacteria (Table 2). The effect of the nitrogen balance on the relationship between $Y_{\text {glucose }}$ and $Y_{\mathrm{O}_{2}}$ is shown in Fig. 1. 


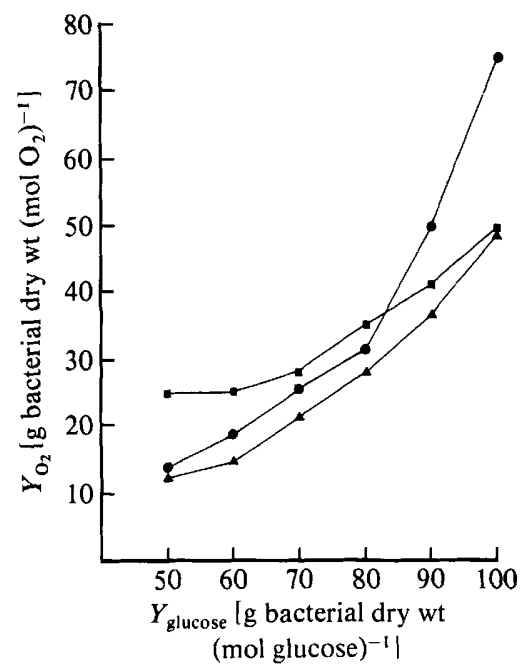

Fig. 1.

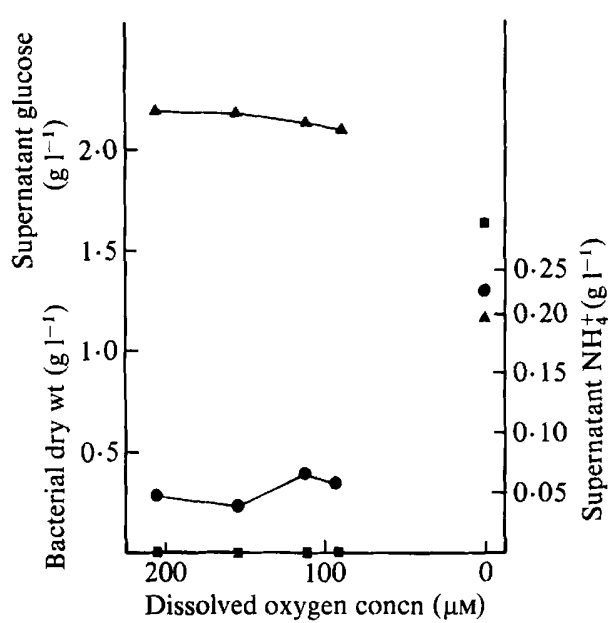

Fig. 2 .

Fig. 1. Theoretical relationship between $Y_{\text {glucose }}$ and $Y_{\mathrm{O}_{2}}$ for $R$. leguminosarum grown aerobically on glucose. The method for determining the values plotted was based on an adapted equation of Herbert (1976) and is described in the text., $\mathrm{NH}_{4}^{+}$not included in calculation, cell empirical formula $=$ $\mathrm{CH}_{2} \mathrm{~N}_{0.25} \mathrm{O}_{0.55} ; \triangle, \mathrm{NH}_{4}^{+}$included in calculation, cell empirical formula $=\mathrm{CH}_{2} \mathrm{~N}_{0.25} \mathrm{O}_{0.55} ; \square, \mathrm{NH}_{4}^{+}$ included in calculation, cell empirical formula $=\mathrm{CH}_{1.84} \mathrm{~N}_{0.22} \mathrm{O}_{0.55}$.

Fig. 2. Relationship between the steady-state DOT, residual glucose and ammonia concentrations, and bacterial dry wt in a glucose- or $\mathrm{O}_{2}$-limited chemostat culture of $R$. leguminosarum. Bacteria were grown at $D=0.1 \mathrm{~h}^{-1}$ under glucose or $\mathrm{O}_{2}$ limitation with $\left(\mathrm{NH}_{4}\right)_{2} \mathrm{SO}_{4}$ as the nitrogen source. The DOT in the culture supernatant was adjusted by altering the ratio of air to nitrogen in the inlet gas stream: $\square$, glucose in supernatant $\left(\mathrm{g} \mathrm{l}^{-1}\right) ; 0$, ammonia in supernatant $\left(\mathrm{g} \mathrm{l}^{-1}\right) ; \Delta$, bacterial dry wt $\left(\mathrm{g} \mathrm{l}^{-1}\right)$. Biomass determinations were based on carbon analysis assuming bacteria contained approximately $45 \%$ carbon (see Table 2).

The experimental values obtained for $Y_{\text {glucose }}^{\max }$ or $Y_{\mathrm{O}_{2}}^{\max }$ agree closely with the theoretically calculated values, e.g. an experimental $Y_{\text {glucose }}^{\max }$ value gave the expected $Y_{\mathrm{O}_{2}}^{\max }$ result when checked against the theoretical $Y_{\mathrm{O}_{2}}^{\max }$ value. A $Y_{\text {glucose }}^{\max }$ value of $84.2 \mathrm{~g}$ bacteria (mol glucose) $)^{-1}$ and $Y_{\mathrm{O}_{2}}^{\max }$ value of $23.8 \mathrm{~g}$ bacteria $\left(\mathrm{mol} \mathrm{O}_{2}\right)^{-1}$ were obtained from data based on bacterial dry weights instead of on carbon analysis. The maintenance energy requirements were $0.031 \mathrm{mmol}$ glucose $\mathrm{g}^{-1} \mathrm{~h}^{-1}$ and $0.023 \mathrm{mmol} \mathrm{O}_{2} \mathrm{~g}^{-1} \mathrm{~h}^{-1}$.

\section{Biomass yield and oxygen limitation}

The culture was grown as described in Methods (except that the glucose and $\left(\mathrm{NH}_{4}\right)_{2} \mathrm{SO}_{4}$ concentrations were approximately $5.0 \mathrm{~g} \mathrm{I}^{-1}$ and $10 \mathrm{mM}$, respectively) at a constant dilution rate $\left(D=0.1 \mathrm{~h}^{-1}\right)$. The steady state dissolved $\mathrm{O}_{2}$ concentration in the culture vessel was maintained at values which ranged from undetectable dissolved $\mathrm{O}_{2}$ to approximately $205 \mu \mathrm{M} \mathrm{O}_{2}$ by alteration of the inflowing air and nitrogen gas flow rates to the fermenter.

A decrease in the steady state biomass concentration was observed with decrease in the steady state DOT (Fig. 2). At undetectable dissolved $\mathrm{O}_{2}$ (i.e. concentrations of dissolved $\mathrm{O}_{2}$ below approximately $2 \mu \mathrm{M}$, the minimum which can be reliably detected with the oxygen electrode), the culture was no longer glucose-limited as there was approximately $1.63 \mathrm{~g}$ glucose $1^{-1}$ in the culture supernatant. The concentration of ammonia in the supernatant also increased (Fig. 2). As all other substrates were in excess, the substrate limiting the growth of $R$. leguminosarum was presumed to be oxygen.

The biomass yield on glucose and $\mathrm{CO}_{2}$ decreased with a decrease in DOT in the culture (Table 3). Unfortunately yields on $\mathrm{O}_{2}$ were not measured because of faulty equipment. 
Table 3. Specific rates of glucose utilization and $\mathrm{CO}_{2}$ production in a glucose/oxygen-limited chemostat culture of $R$. leguminosarum

Bacteria were grown at $D=0.1 \mathrm{~h}^{-1}, 28^{\circ} \mathrm{C}$ and $\mathrm{pH} 6.8$. The dissolved oxygen concentration in the culture supernatant was adjusted by altering the ratio of air to nitrogen in the inlet gas stream. The carbon recovery values were calculated from carbon recovered as [(total outlet carbon)/(total inlet carbon)] $\times 100$. Yield values were calculated from the equation $Y=D / q_{\text {substrate }}$.

$\begin{array}{cc}\begin{array}{c}\text { Dissolved } \\ \text { oxygen concn } \\ \text { in chemostat } \\ (\mu \mathrm{M})\end{array} & \begin{array}{c}q_{\text {glucose }} \\ \text { [mmol glucose } \\ \text { consumed } \\ (\mathrm{g} \text { dry } \mathrm{wt})^{-1} \mathrm{~h}^{-1} \text { ] }\end{array} \\ 205.5 & 1.425 \\ 143.1 & 1.37 \\ 110.3 & 1.47 \\ 94.6 & 1.56 \\ 0 & 1.72\end{array}$

$\begin{gathered}Y_{\text {glucose }} \\ \text { [g dry wt } \\ \text { bacteria } \\ \text { (mol glucose) }^{-1} \text { ] }\end{gathered}$
$70 \cdot 2$
$73 \cdot 0$
$68 \cdot 0$
$64 \cdot 1$
$58 \cdot 0$

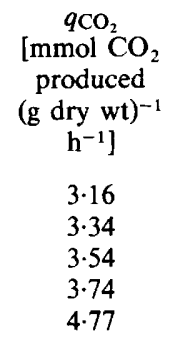

$\begin{array}{cc}\begin{array}{c}\mathrm{CO}_{2} \\ {[\mathrm{~g} \mathrm{dry} \mathrm{wt}} \\ \text { bacteria } \\ \left.\left(\mathrm{mol} \mathrm{CO}_{2}\right)^{-1}\right]\end{array} & \begin{array}{c}\text { Carbon } \\ \text { recovery } \\ (\%)\end{array} \\ 31 \cdot 6 & 93 \\ 29 \cdot 9 & 101 \\ 28 \cdot 3 & 94 \\ 26 \cdot 7 & 93 \\ 21 \cdot 0 & 99\end{array}$

\section{$\mathrm{H}^{+} \mathrm{O}$ ratios in $\mathrm{R}$. leguminosarum grown at different dissolved oxygen concentrations in a glucose-limited chemostat}

The effect of DOT on the $\mathrm{H}^{+} / \mathrm{O}$ ratios in free-living $R$. leguminosarum was examined as described in Methods. In this series of experiments it was often impossible to obtain reproducible results when the organisms were maintained in a state of preparation for the experiment, i.e. when the organisms were washed, centrifuged and resuspended in buffer $\left(140 \mathrm{~mm}-\mathrm{KCl}, 1 \mathrm{~mm}\right.$-Tris at $\mathrm{pH} 7 \cdot 0$ ). The results (Table 4) deviated from the expected $\mathrm{H}^{+} / \mathrm{O}$

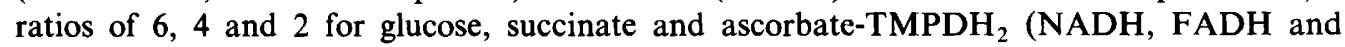
cytochrome $c$ linked substrates), respectively (Mitchell \& Moyle, 1979). $\mathrm{H}^{+} / \mathrm{O}$ ratios were obtained in all cases with endogenous substrate even though the organisms were grown in a glucose-limited (i.e. carbon-limited) chemostat. A feature of the proton pulse experiments was the rapid collapse of the pulse, with a $t_{\frac{1}{2}}$ (time for pulse height to decrease by $50 \%$ ) of between 12 and $15 \mathrm{~s}$.

The reason for the irreproducibility of the results was difficult to determine. The ability of the organisms to oxidize glucose $(5 \mathrm{mM})$ and succinate $(5 \mathrm{mM})$, when washed and resuspended in $15 \mathrm{~mm}$-phosphate buffer ( $\mathrm{pH} \mathrm{6.8)}$ ), after removal from the chemostat, was examined and found to remain almost constant over a $6 \mathrm{~h}$ period. The $K_{\mathrm{s}}$ of $R$. leguminosarum for succinate-dependent $\mathrm{O}_{2}$ uptake, grown glucose-limited at $D=0.1 \mathrm{~h}^{-1}$, was approximately $1.2 \mathrm{mM}$ and that for glucose-dependent $\mathrm{O}_{2}$ uptake was 10 to $60 \mu \mathrm{M}$.

\section{Cytochrome content of $\mathrm{R}$. leguminosarum grown under $\mathrm{O}_{2} /$ glucose limitation}

The quantity of cytochromes $c_{550}, c_{555}, b_{560}$ and cytochrome oxidase $a a_{3}$ as a percentage of the total peak heights in $R$. leguminosarum grown at different values of DOT is given in Table 5 . The unequivocal appearance of an adsorption maximum at $630 \mathrm{~nm}$ (possibly cytochrome $d$ ) at zero detectable dissolved oxygen is apparent (Fig. 3c). This peak was also present at $95 \mu \mathrm{M}$ DOT in the chemostat. CO-reduced minus reduced difference spectra indicated that cytochrome $o$ was present at all dissolved oxygen concentrations.

\section{DISCUSSION}

The values of $Y_{\text {glucose }}^{\max }$ and $Y_{\text {oxygen }}^{\max }$ for $R$. leguminosarum grown glucose-limited were much lower than values reported for other similar cultures of heterotrophic bacteria having two or three sites of oxidative phosphorylation with $\mathrm{O}_{2}$ as the terminal electron acceptor. For example, Jones et al. (1977) found $\mathrm{Y}_{\mathrm{O}_{2}}^{\max }$ values of 91.0 and $61.9 \mathrm{~g}$ bacteria $\left(\mathrm{mol} \mathrm{O}_{2}\right)^{-1}$ for glucose-limited bacterial cultures which respectively contained or lacked cytochrome $c$. Also, a low $Y_{\mathrm{O}_{2}}^{\max }$ value 


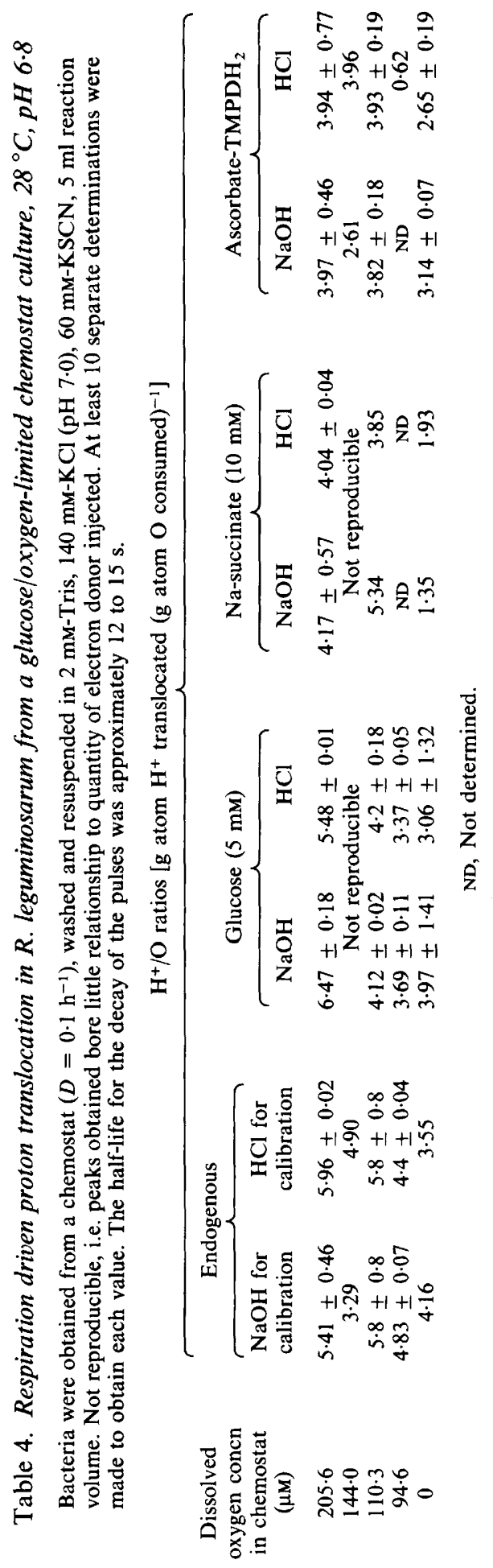


Table 5. Relative contents of cytochromes in $R$. leguminosarum grown at different dissolved oxygen concentrations in a glucose-limited chemostat

Bacteria were grown at $D=0.1 \mathrm{~h}^{-1}$ and $28^{\circ} \mathrm{C}, \mathrm{pH} 6.8$ and prepared using the procedure described in Methods. Reduced minus oxidized spectra were recorded at $77 \mathrm{~K}$. Values shown are percentages of the total cytochromes present in each case as measured by peak heights. Cytochrome $o$ was present in each case in CO-reduced minus reduced spectra. The presence of cytochrome $c_{550}$ was not definite although there was a slight shoulder on the $c_{555}$ peak. Two values for the cytochrome concentrations at zero detectable dissolved oxygen are given because it was difficult to establish conclusively whether cytochrome $c_{550}$ was present (see Fig. $3 c$ ). Bacterial concentration was $12 \cdot 0 \mathrm{~g}^{-1}$.

Dissolved oxygen

concn in fermenter

\begin{tabular}{|c|c|c|c|c|c|}
\hline$(\mu \mathrm{M})$ & $c_{550}$ & $c_{555}$ & $b_{560}$ & $a a_{3596}$ & $d_{630}$ \\
\hline $205 \cdot 6$ & 33.6 & $28 \cdot 6$ & $26 \cdot 1$ & $11 \cdot 8$ & 0 \\
\hline 144.0 & 29.9 & 29.0 & $27 \cdot 6$ & $13 \cdot 0$ & 0 \\
\hline $110 \cdot 3$ & 31.6 & $29 \cdot 1$ & $27 \cdot 2$ & $12 \cdot 1$ & 0 \\
\hline $94 \cdot 6$ & $28 \cdot 1$ & 26.9 & $26 \cdot 6$ & $11 \cdot 8$ & 6.6 \\
\hline 0 & $17 \cdot 6$ & $27 \cdot 4$ & $26 \cdot 0$ & 16.0 & $12 \cdot 9$ \\
\hline 0 & 0 & $33 \cdot 3$ & $31 \cdot 6$ & $19 \cdot 5$ & $15 \cdot 6$ \\
\hline
\end{tabular}

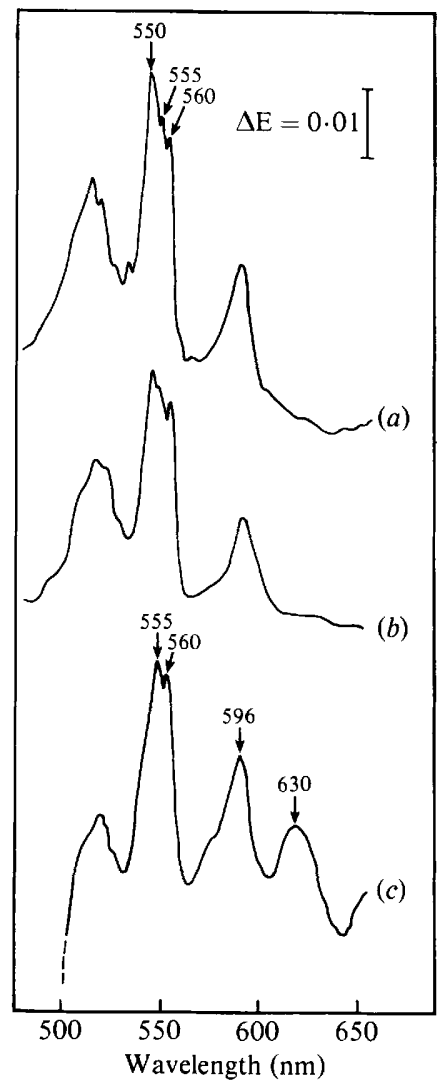

Fig. 3. Cytochrome content of $R$. leguminosarum grown at different DOT values in glucose- or $\mathrm{O}_{2}$ limited chemostat cultures. Cytochrome contents of intact bacteria (approximately $12.0 \mathrm{~g} \mathrm{l}^{-1}$ ), from a glucose-limited or $\mathrm{O}_{2}$-limited chemostat $\left(D=0 \cdot 1 \mathrm{~h}^{-1}\right)$ measured in cuvettes of $1 \mathrm{~mm}$ light path length, at $77 \mathrm{~K}$. Reduced (dithionite) minus oxidized $\left(\mathrm{H}_{2} \mathrm{O}_{2}\right)$ difference spectra. (a) Dissolved oxygen concentration in chemostat $=205.6 \mu \mathrm{M} ;(b)$ dissolved oxygen concentration in chemostat $=110 \cdot 3 \mu \mathrm{M}$; (c) dissolved oxygen concentration in chemostat $=$ undetectable. 
[approximately $33.3 \mathrm{~g}$ dry wt (mol oxygen) ${ }^{-1}$ ] can be calculated for $R$. trifolii, from the data of de Hollander et al. (1979), when grown carbon-limited on mannitol with asparagine as the nitrogen source. There could be several explanations for these low yields in rhizobia.

Simpson et al. (1979) and Peterson \& Evans (1979) indicate that considerable quantities of $\mathrm{CO}_{2}$ can be fixed by $R$. japonicum. The low $Y_{\mathrm{O}_{2}}^{\max }$ and $Y_{\text {glucose }}^{\max }$ values we observed for $R$. leguminosarum could be explained if the bacteria fixed considerable quantities of $\mathrm{CO}_{2}$; this is an energy- and reductant-dependent process and would cause a decrease in the biomass yields on oxygen and glucose. The carbon recovery values obtained of approximately $100 \pm 6 \%$ indicate, on the assumption that the input of carbon as $\mathrm{CO}_{2}$ was negligible, that substantial $\mathrm{CO}_{2}$ fixation was unlikely. This conclusion is supported by the fact that the observed values for $Y_{\text {glucose }}^{\max }$ and $Y_{\mathrm{O}_{2}}^{\max }$ agreed closely with the theoretical values in which no $\mathrm{CO}_{2}$ fixation (or $\mathrm{H}_{2}$ evolution) was assumed.

The low yields of $R$. leguminosarum on glucose and $\mathrm{O}_{2}$ could also be due to the production of 'overflow' metabolites, e.g. acetate or polysaccharide production, a low $\mathrm{P} / \mathrm{O}$ ratio, nitrogen fixation or $\mathrm{H}_{2}$ evolution. The absence of $\mathrm{H}_{2}$ in the influent and effluent gas streams indicated that the organisms could neither be oxidizing $\mathrm{H}_{2}$ to obtain energy, nor producing hydrogen. Nitrogen fixation can be discounted as the rhizobia were growing at a DOT of approximately $200 \mu \mathrm{M}$, well above the $\mathrm{O}_{2}$ concentration inhibitory to nitrogenase activity in rhizobia (Bergersen et al., 1976). The production of large amounts of overflow metabolites, although not directly measured, would have been apparent in the carbon recovery values and in the supernatant carbon values which were always very low for the glucose-limited cultures. Carbon recovery values near $100 \%$ were obtained for such cultures.

A P/O ratio of 3 is expected for bacteria grown aerobically on the assumption of a normal rate of $\mathrm{H}^{+}$decay ( $t_{\frac{1}{2}}$ of 40 to $60 \mathrm{~s}$ ), the presence of cytochrome $c$ and absence of cytochrome $d$ in the respiratory chain. Jones et al. (1977) reported a $Y_{\text {glucose }}^{\max }$ value of $100 \mathrm{~g}$ dry wt (mol glucose) $)^{-1}$ for Arthrobacter globiformis and $110.0 \mathrm{~g}$ dry wt (mol glucose) ${ }^{-1}$ for Paracoccus denitrificans grown aerobically on glucose with corresponding $Y_{\mathrm{O}_{2}}^{\max }$ values of 92.0 and $90.0 \mathrm{~g}$ dry wt $\left(\mathrm{mol} \mathrm{O}_{2}\right)^{-1}$, respectively. Therefore, from the relationship $Y_{\mathrm{O}_{2}}^{\max }=Y_{\mathrm{ATP}}^{\max }(2 \times \mathrm{P} / \mathrm{O})$, a $Y_{\mathrm{ATP}}^{\max }$ value of $15.0 \mathrm{~g}$ dry wt (mol ATP $)^{-1}$ would be obtained if a $Y_{\mathrm{O}_{2}}^{\max }$ value of $90 \mathrm{~g}$ dry wt $\left(\mathrm{mol} \mathrm{O}_{2}\right)^{-1}$ was used. There is no reason to assume that the $Y_{A T P}^{\max }$ value for non-nitrogen fixing rhizobia is less than approximately $15.0 \mathrm{~g}$ dry wt $(\mathrm{mol})^{-1}$ when grown aerobically with glucose and minimal salts. Consequently, the $Y_{\mathrm{O}_{2}}^{\max }$ value of $26.0 \mathrm{~g}$ dry wt (mol oxygen) $)^{-1}$ for $R$. leguminosarum with a $Y_{\mathrm{ATP}}$ of 15 results in a $\mathrm{P} / \mathrm{O}$ ratio of approximately 1 . However, the $\rightarrow \mathrm{H}^{+} / \mathrm{O}$ ratios (Table 4) indicated a potential of 3 proton translocating loops, discounting transhydrogenase activity which is unlikely to give ATP production under normal physiological conditions. Proton translocation studies revealed that the $t_{\frac{1}{2}}$ for the decay of the proton pulse was extremely rapid, between 12 and $15 \mathrm{~s}$, approximately three times faster than commonly found. This increased rate of proton decay may mean that the effective $\mathrm{P} / \mathrm{O}$ ratio was only one, i.e. the overall $\mathrm{H}^{+} / \mathrm{ATP}$ ratio $\left[\mathrm{g}\right.$ atom $\mathrm{H}^{+}$ (mol ATP synthesized) ${ }^{-1}$ ] was 6 and that the three times increased rate of decay reflected this. At present it is not known how this fast rate of decay is mediated although it may be due to a general leakiness of the bacterial membrane to protons, a 'gate' in the ATPase, an antiport or symport mechanism for transport of protons across the cell membrane, or the action of some unknown uncoupler. Recently McKay et al. (1982) observed similar low yields on glucose and $\mathrm{O}_{2}$ and a very high permeability of the cytoplasmic membrane to protons in the extreme thermophile Thermus thermophilus HB8.

The results from the experiments with $R$. leguminosarum grown at a dilution rate of $0 \cdot 1 \mathrm{~h}^{-1}$ with various DOT values showed a decrease in the observed $Y_{\text {glucose }}$ and $Y_{\mathrm{O}_{2}}$ values with decrease in the DOT. This could be due to the production of cytochrome oxidase $d$ with an associated decrease in the efficiency of respiratory chain energy conservation (Jones, 1978) or factors already discussed. Bergersen \& Turner (1980) found that rhizobia which infect cowpea and soybean when grown in continuous culture under $\mathrm{O}_{2}$ limitation produced cytochrome oxidases with a high affinity for $\mathrm{O}_{2}$; these oxidases were also found in the corresponding bacteroids (Bergersen \& Turner, 1975, 1980). A decrease in the efficiency of respiratory chain energy conservation in $R$. leguminosarum was confirmed by the $\mathrm{H}^{+} / \mathrm{O}$ ratios (Table 4). The $\mathrm{H}^{+} / \mathrm{O}$ ratios 
for bacteria grown at DOT values above those limiting growth indicated a 'potential' $\mathrm{P} / \mathrm{O}$ ratio of approximately 3 for endogenous substrate and glucose, and approximately 2 for succinate and ascorbate- $\mathrm{TMPDH}_{2}$. The high $\mathrm{H}^{+} / \mathrm{O}$ ratios obtained with ascorbate- $\mathrm{TMPDH}_{2}$ as electron donor were probably due to the presence of intracellular NADH and FADH, as it was not possible to starve the cells. However, the $\mathrm{H}^{+} / \mathrm{O}$ ratio with either endogenous substrate or glucose for bacteria grown oxygen-limited indicated a 'potential' $\mathrm{P} / \mathrm{O}$ ratio of approximately 2 .

The results reported in this paper indicate that the effective $\mathrm{P} / \mathrm{O}$ ratio in free-living $R$. leguminosarum was near 1 although there were three proton-translocating loops present, i.e. the overall $\mathrm{H}^{+} /$ATP ratio was near 6 and not 2 (although the catalytic $\mathrm{H}^{+} /$ATP ratio may still be 2, but protons are leaking through the cytoplasmic membrane rather than the ATPase). Similar rapid rates of decay in respiration induced proton pulses were also seen in batch culture grown $R$. japonicum 705 and $R$. japonicum $32 \mathrm{H} 1$ (H. D. Ratcliffe \& J. W. Drozd, unpublished observations). If rhizobia exhibited this same low efficiency of energy conservation when fixing dinitrogen in the root nodule of host legume it would provide a low efficiency of $\mathrm{N}_{2}$ fixation with respect to the amount of carbon (plant photosynthate) oxidized. However, the bacteroids from soybean root nodules exhibited respiration-driven proton translocation with no such rapid rate of proton decay (Ratcliffe et al., 1980). The low $Y_{\mathrm{O}_{2}}$ values and high respiration rates for axenic cultures of $R$. leguminosarum might indicate that free-living rhizobia have some form of respiratory protection mechanism, analogous to, but much less well developed than that in Azotobacter (Drozd, 1978). Such a mechanism would not be required when in symbiotic association within the root nodule of a host legume when the maintenance substrate consumption would also presumably be minimized.

H.D. R. is grateful to the Science Research Council for a CASE Research Studentship. We would like to thank Mr L. J. Barnes and Mr M. E. Collins for their technical aid and Mrs K. Shaw for C, H and N analyses.

\section{REFERENCES}

Appleby, C. A., Turner, G. L. \& Macnicol, P. K (1975). Involvement of oxyhaemoglobin and cytochrome P-450 in an efficient oxidative phosphorylation pathway which supports nitrogen fixation in Rhizobium. Biochimica et biophysica acta 387, 461-474.

Bergersen, F. J. \& TURner, G. L. (1975). Leghaemoglobin and the supply of $\mathrm{O}_{2}$ to nitrogen-fixing root nodule bacteroids: presence of two oxidase systems and ATP production at low free $\mathrm{O}_{2}$ concentration. Journal of General Microbiology 91, 345-354.

Bergersen, F. J. \& Turner, G. L. (1980). Properties of terminal oxidase systems of bacteroids from root nodules of soybean and cowpea and of $\mathrm{N}_{2}$-fixing bacteria grown in continuous culture. Journal of General Microbiology 118, 235-252.

Bergersen, F. J., Turner, G. L., Gibson, A. H. \& DUdMAN, W. F. (1976). Nitrogenase activity and respiration of cultures of Rhizobium spp. with special reference to concentration of dissolved oxygen. Biochimica et biophysica acta 444, 164-174.

Deans, D. R., Huckle, M. T. \& Peterson, R. M. (1971). A new column system for isothermal gas chromatographic analysis of light gases $\left(\mathrm{H}_{2}, \mathrm{O}_{2}, \mathrm{~N}_{2}\right.$, $\mathrm{CO}, \mathrm{CH}_{4}, \mathrm{C}_{2} \mathrm{H}_{4}, \mathrm{C}_{2} \mathrm{H}_{5}$ ) employing a column switch technique. Chromatographia 4, 279-285.

DRozD, J. W. (1978). Respiration and energy conservation in Azotobacter vinelandii. FEMS Microbiology Letters 3, 47-49.

Farmer, I. S. \& Jones, C. W. (1976). The effect of temperature on the molar growth yield and main- tenance requirement of Escherichia coli during aerobic growth in continuous culture. FEBS Letters 67, 359-363.

HERBERT, D. (1976). Stoichiometric aspects of microbial growth. In Continuous Culture 6, Applications and New Fields, pp. 1-30. Edited by A. C. R. Dean, D. C. Ellwood \& H. Melling. Chichester: Ellis Horwood Publishers.

de Hollander, J. A., Bettenhaussen, C. W. \& Stouthamer, A. H. (1979). Growth yields, polysaccharide production and energy conservation in chemostat cultures of Rhizobium trifolii. Antonie van Leeuwenhoek 45, 401-405.

JONES, C. W. (1978). Microbial oxidative phosphorylation. Biochemical Society Transactions 6, 361-363.

Jones, C. W., Brice, J. M., Downs, A. J. \& Drozd, J. W. (1975). Bacterial respiration-linked proton translocation and its relationship to respiratory-chain composition. European Journal of Biochemistry 52 , 265-271.

Jones, C. W., Brice, J. M. \& Edwards, C. (1977). The effect of respiratory chain composition on the growth efficiencies of aerobic bacteria. Archives of Microbiology 115, 85-93.

laAne, C., HaAker, H. \& Veeger, C. (1978). Involvement of the cytoplasmic membrane in nitrogen fixation by Rhizobium leguminosarum bacteroids. European Journal of Biochemistry 87, 147-153.

Linton, J. D., Harrison, D. E. F. \& Bull, A. T. (1975). Molar growth yields, respiration and cytochrome patterns of Beneckea natriegens when grown 
under different medium dissolved oxygen tensions. Journal of General Microbiology 90, 237-246.

MCKay, A., Quilter, J. \& Jones, C. W. (1982). Energy conservation in the extreme thermophile Thermus thermophilus HB8. Archives of Microbiology 131, 43-50.

Mitchell, P. \& Moyle, J. (1967). Respiration driven proton translocation in rat liver mitochondria. Biochemical Journal 105, 1147-1162.

Petersen, J. B. \& Evans, H. J. (1979). Phosphoenolpyruvate carboxylase from soybean nodule cytosol. Evidence for the isoenzymes and kinetics of the most active component. Biochimica et biophysica acta 567, 448-452.
Ratcliffe, H. D., Drozd, J. W. \& Bull, A. T. (1979). Energy coupling in Rhizobium sp. Proceedings of the Society for General Microbiology 6, 72-73.

Ratcliffe, H. D., Drozd, J. W., Bull, A. T. \& DANIEL, R. M. (1980). Energy coupling in soybean bacteroids. FEMS Microbiology Letters 8, 111115.

Simpson, F. B., Maier, R. J. \& Evans, H. J. (1979). Hydrogen-stimulated $\mathrm{CO}_{2}$ fixation and co-ordinate induction of hydrogenase and ribulose bisphosphate carboxylase in a $\mathrm{H}_{2}$ uptake positive strain of Rhizobium japonicum. Archives of Microbiology 123, 1-8. 